\title{
PENGARUH KOMITMEN ORGANISASI, PROFESIONALISME DAN KOMPETENSI GURU TERHADAP KINERJA GURU DI SMPN I IDI KABUPATEN ACEH TIMUR
}

\author{
Suriani \\ Universitas Islam Sumatera Utara \\ surianimm@gmail.com
}

\begin{abstract}
The superiority of a nation no longer rests on natural wealth, but on the superiority of human resources, one of which is the teaching staff (teachers) who are able to answer challenges very quickly. Education is basically an effort to develop human resources, although efforts to develop human resources are not only carried out through education, especially formal education or schools, but until now, education is still seen as a means and vehicle for developing human resources that is carried out systematically, programmatic, and tiered. Performance is an outcome that must be done by a teacher to produce students so that a teacher's professionalism and teacher competence are supported by organizational commitment. Yan Kinerjag becomes the problem in this research is How the influence of Organizational Commitment, Professionalism and Teacher Competence on Teacher Performance in IDI Middle School, East Aceh Regency. As for the results of this study Performance $=19,768+, 110 X 1+, 118$ X2 +, 349 X3 Based on the results of these equations, an explanation can be described as follows: Constant value of 19.768 gives the meaning that if overall the value of variables Organizational Commitment, Professionalism and Teacher Competence) increase by la respectively, the value of Performance ( $Y$ ) will rise to 19,768. The coefficient value of Organizational Commitment of 0.110 means that if the value of Organizational Commitment increases by $1 a$, the value of performance will also increase by 0.110. A positive coefficient value means that Organizational Commitment has a positive influence on Performance. Professionalism coefficient value of 0.118 means that if the value of Professionalism increases by $1 a$, the performance value will also increase by 0.118. A positive coefficient value means that Professionalism has a positive influence on Performance. The Teacher Competency coefficient value of 0.349 means that if the Teacher Competency value increases by la, the performance value will also increase by 0.349. A positive coefficient value means that Teacher Competence has a positive influence on Performance.
\end{abstract}

Keywords: Organizational Commitment, Professionalism, Teacher Competence.

ABSTRAK : Keunggulan suatu bangsa tidak lagi bertumpu pada kekayaan alam, melainkan pada keunggulan sumber daya manusia, salah satunya adalah tenaga pendidik (guru) yang mampu menjawab tantangan-tantangan yang sangat cepat. Pendidikan pada dasarnya merupakan suatu usaha pengembangan sumber daya manusia, walaupun usaha pengembangan sumber daya manusia tidak hanya dilakukan melalui pendidikan khususnya pendidikan formal atau sekolah, akan tetapi sampai saat ini, pendidikan masih dipandang sebagai sarana dan wahana untuk pengembangan sumber daya manusia yang dilakukan dengan sistematis, programatis, dan berjenjang .Kinerja merupakan satu hasil yang harus dilakukan oleh seseorang guru untuk menghasilkan anak didik sehingga diperlukan profesionalisme seorang guru serta kompetensi guru dengan didukung oleh komitmen organisasi. Yan Kinerjag menjadi permasalahan dalam penelitian ini adalah Bagaimana pengaruh Komitmen Organisasi, Profesionaslisme dan Kompetensi Guru terhadap KinerjaGuru di SMPN I IDI Kabupaten Aceh Timur. Adapun hasil penelitian iniKinerja $=19,768 C+, 110 X^{1}+, 118 X^{2}+, 349 X^{3}$ Berdasarkan hasil persamaan tersebut maka dapat diuraikan penjelasan sebagai berikut :Nilai Konstanta sebesar 19,768 memberikan arti bahwa jika secara keseluruhan nilai variable (SinismeX ${ }^{1}$, Kecerdasan EmosionalX $X^{2}$, Stres Kerja $X^{3}$ ) naik masing sebesar $1_{a}$ maka nilai Kinerja (Y) akan naik menjadi 19,768. Nilai koefisien Komitmen organisasi sebesar 0,110 memberikan arti bahwa jika nilai Komitmen Organisasi naik sebesar $1_{a}$ 
maka nilai kinerja juga akan naik sebesar 0,110. Nilai koefisien yang positif memberikan arti bahwa Komitmen Organisasi memberikan pengaruh positif terhadap Kinerja.Nilai koefisien Profesionalisme sebesar 0,118 memberikan arti bahwa jika nilai Profesionalisme naik sebesar $1_{a}$ maka nilai kinerja juga akan naik sebesar 0,118. Nilai koefisien yang positif memberikan arti bahwa Profesionalisme memberikan pengaruh positif terhadap Kinerja.Nilai koefisien Kompetensi Guru sebesar 0,349 memberikan arti bahwa jika nilai Kompetensi Guru naik sebesar $1_{a}$ maka nilai kinerja juga akan naik sebesar 0,349. Nilai koefisien yang positif memberikan arti bahwa Kompetensi Guru memberikan pengaruh positif terhadap Kinerja.

Kata kunci: Komitmen Organisasi, Profesionalisme , Kompetensi Guru.

\section{Pendahuluan}

Keunggulan suatu bangsa tidak lagi bertumpu pada kekayaan alam, melainkan pada keunggulan sumberdaya manusia, salah satunya adalah tenaga pendidik (guru) yang mampu menjawab tantangan - tantangan yang sangat cepat. Pendidikan pada dasarnya merupakan suatu usaha pengembangan sumberdaya manusia, walaupun usaha pengembangan sumberdaya manusia tidak hanya dilakukan melalui pendidikan khususnya pendidikan formal atau sekolah, akan tetapi sampai saat ini, pendidikan masih dipandang sebagai sarana dan wahana untuk pengembangan sumberdaya manusia yang dilakukan dengan sistematis, programatis, dan berjenjang. Sumberdaya yang unggul dapat dilihat dari hasil kerja atau kinerja dalam melakukan suatu pekerjaan.

Beberapa factor yang mempengaruhi kinerja yaitu komitmen organisasi. Komitmen organisasi yang jelas yang mana untuk menyamankan para guru sebagai pelaku organisasi, juga untuk menunjang hal tersebut dibutuhkan Profesionalisme dan kompetensi Guru yang baik dalam hal proses pendidikan, sehingga akan didapat kinerja guru yang maksimal seperti yang diharapkan. (Muslikah, 2016:37). Selanjutnya Menurut penelitian (Aditya Reza,2010:35) Guru merupakan salah satu factor strategis dalam menentukan keberhasilan pendidikan karena gurulah yang meletakkan dan mempersiapkan dasar perkembangan potensi peserta didik untuk masa depan bangsa. Untuk melaksanakan itu, tentu diperlukan guru yang memiliki profesionalisme tinggi.

Istilah profesionalisme identik dengan sifat dan perilaku seseorang yang berkompeten, berpendidikan, berdedikasi, bertanggungjawab, jujur, dan loyal pada pekerjaannya. Profesionalisme guru merupakan kondisi, arah, nilai, tujuan, dan kualitas suatu keahlian dan kewenangan dalam bidang pendidikan dan pengajaran yang berkaitan dengan pekerjaan seseorang yang menjadi mata pencaharian. Sementara itu, guru yang professional adalah guru yang memiliki kompetensi yang dipersyaratkan untuk melakukan tugas pendidikan dan pengajaran. Dengan kata lain, maka dapat disimpulkan bahwa pengertian guru professional adalah orang yang memiliki kemampuan dan keahlian khusus dalam bidang keguruan sehingga ia mampu melakukan tugas dan fungsinya sebagai guru dengan kemampuan maksimal.

Fenomena yang didapatkan dari hasil observasi berkaitan dengan beberapa variable diatas adalah tidak adanya komitmen para guru dalam hal mengajar, system mengajar semaunya saja sehingga tidak ada ke profesionalisme dan kompetensi guru. Saat jam belajar murid lebih banyak bermain dan tidak produktif dalam menimba ilmu. Sehingga Profesionalisme dan Kompetensi guru dipertanyakan dan menjadi pokok permasalahan dalam hal penilaian kinerja guru.

Oleh karena itu, berdasarkan uraian permasalahan tersebut diatas peneliti tertarik untuk melakukan penelitian mengenai Pengaruh Komitmen Organisasi, Profesionalisme dan Kompetensi Guru terhadap Kinerja guru di SMPN I IDI Kabupaten Aceh Timur.

Tujuan dilakukannya penelitian ini adalah :

1. Untuk menganalisis Pengaruh Komitmen Organisasi terhadap Kinerja guru di SMPN I IDI Kabupaten Aceh Timur

2. Untuk menganalisis Pengaruh Profesionalisme terhadap Kinerja guru di SMPN I IDI Kabupaten Aceh Timur

3. Untuk menganalisis Pengaruh Kompetensi Guru terhadap Kinerja guru di SMPN I IDI Kabupaten Aceh Timur

4. Untuk menganalisis Pengaruh Komitmen Organisasi, Profesionalisme dan Kompetensi 
Guru terhadap Kinerja guru di SMPN I IDI Kabupaten Aceh Timur

\section{Metode Penelitian}

\subsection{Populasi dan Sampel}

Populasi adalah wilayah generalisasi yang terdiri atas obyek/subjek yang mempunyai kuantitas dan karakteristik tertentu yang ditetapkan oleh peneliti untuk dipelajari dan kemudian ditarik kesimpulannya. (Sevilla,2008:82). Dari pengertian tersebut, maka dapat disimpulkan bahwa populasi merupakan subjek penelitian sebagai keseluruhan objek penelitian yang akan diteliti. Dengan teknik penarikan sampel secara total sampling maka yang menjadi sampel dalam penelitian ini adalah seluruh populasi yaitu 32 orang di SMPN I IDI Kabupaten Aceh Timur

\subsection{Definisi OPerasional Variabel}

Definisi operasional variable penelitian ini dijelaskan pada table 1 berikut ini :

Tabel 1

Defenisi Operasional Variabel

\begin{tabular}{|c|c|c|}
\hline $\begin{array}{c}\text { Variabel } \\
\text { Penelitian }\end{array}$ & Definisi Operasional & Indikator \\
\hline $\begin{array}{l}\text { Komitmen } \\
\text { Organisasi } \\
\text { (X1) }\end{array}$ & $\begin{array}{l}\text { Komitmen organisasi adalah suatu } \\
\text { keadaan dimana seseorang karyawan } \\
\text { memihak terhadap tujuan-tujuan } \\
\text { organisasi serta memiliki keinginan } \\
\text { untuk mempertahankan } \\
\text { keanggotaannya dalam organisasi } \\
\text { tersebut. Robbindan Judge (2008) }\end{array}$ & $\begin{array}{l}\text { a) Kemauan Karyawan } \\
\text { b) Kesetiaan Karyawan } \\
\text { c) Kebanggaan Karyawan }\end{array}$ \\
\hline $\begin{array}{l}\text { Profesionali } \\
\text { sme (X2) }\end{array}$ & $\begin{array}{l}\text { Profesionalisme guru merupakan suatu } \\
\text { tingkah laku, suatu tujuan atau } \\
\text { rangkaian kualitas yang menandai atau } \\
\text { melukiskan corak suatu profesi. Uzer } \\
(2013: 109)\end{array}$ & $\begin{array}{l}\text { a) Kualifikasi Akademi. } \\
\text { b) Pendidikan dan Pelatihan. } \\
\text { c) Pengalaman Mengajar. } \\
\text { d) Perencanaan dan pelaksanaan } \\
\text { pembelajaran } \\
\text { e) Prestasi Akademi } \\
\text { f) Karya Pengembangan Profesi. } \\
\text { g) Keikut sertaan dalam Forum Ilmiah. } \\
\text { h) Penghargaan yang relevan dengan } \\
\text { bidang pendidikan. }\end{array}$ \\
\hline $\begin{array}{l}\text { Kompetensi } \\
\text { (X3) }\end{array}$ & $\begin{array}{l}\text { MenurutpendapatMuhibinSyah } \\
\text { (2011:154) Kompetensiadalah" } \\
\text { KemampuanatauKecakapan” } \\
\text { pengertianinidperkuatolehPoerwadama } \\
\text { rminta (2008: 85)bahwa yang } \\
\text { dimaksuddenganKompetensiadalah “ } \\
\text { Keterampilanataukekuasaanuntukmene } \\
\text { ntukanataumemutuskansuatuhal. }\end{array}$ & $\begin{array}{l}\text { a) Menguasai bahan } \\
\text { b) Mengelola program belajar mengajar } \\
\text { c) Mengelola Kelas } \\
\text { d) Menggunakan media atau sumber } \\
\text { belajar. } \\
\text { e) Menguasai landasan-landasan } \\
\text { kependidikan } \\
\text { f) Mengelola interaksi belajar mengajar. } \\
\text { g) Menilai prestasi siswa untuk pendidik } \\
\text { dan pengajar. } \\
\text { h) Mengenal fungsi dan program } \\
\text { pelayanan bimbingan dan penyeluhan. }\end{array}$ \\
\hline $\begin{array}{l}\text { Kinerja } \\
\text { Guru (Y) }\end{array}$ & $\begin{array}{l}\text { Kinerja adalah hasil dari satu yang } \\
\text { dilakukan seseorang dan menghasilkan } \\
\text { apa yang di sepakati sesuai dengan } \\
\text { kesepakatan yang di lakukan . Mathis } \\
\text { dan Jackson (2012:367) }\end{array}$ & $\begin{array}{l}\text { a) Kualitas } \\
\text { b) Kuantitas } \\
\text { c) Keandalan } \\
\text { d) BekerjaSama } \\
\text { e) KetepatanWaktu }\end{array}$ \\
\hline
\end{tabular}

\subsection{Pengujian Validitas}

Suharsimi (2010), dalam penelitian ini nilai validitas dicari dengan menggunakan rumus korelasi product moment dari Pearson. 
Tabel 2

Uji Validitas Variabel $\mathrm{X}_{1}$

\begin{tabular}{|c|c|c|c|}
\hline Pertanyaan & $\mathbf{r}_{\text {hitung }}$ & $\mathbf{r}_{\text {tabel }}$ & Keterangan \\
\hline 1 & 0,288 & 0,220 & Valid \\
\hline 2 & 0,149 & 0,220 & Valid \\
\hline 3 & 0,482 & 0,220 & Valid \\
\hline 4 & 0,413 & 0,220 & Valid \\
\hline 5 & 0,780 & 0,220 & Valid \\
\hline 6 & 0,573 & 0,220 & Valid \\
\hline 7 & 0,452 & 0,220 & Valid \\
\hline 8 & 0,829 & 0,220 & Valid \\
\hline 9 & 0,732 & 0,220 & Valid \\
\hline 10 & 0,042 & 0,220 & Valid \\
\hline
\end{tabular}

Tabel 3

Uji Validitas Variabel $\mathrm{X}_{2}$

\begin{tabular}{|c|c|c|c|}
\hline Pertanyaan & $\mathbf{r}_{\text {hitung }}$ & $\mathbf{r}_{\text {tabel }}$ & Keterangan \\
\hline 1 & 0,623 & 0,220 & Valid \\
\hline 2 & 0,581 & 0,220 & Valid \\
\hline 3 & 0,354 & 0,220 & Valid \\
\hline 4 & 0,689 & 0,220 & Valid \\
\hline 5 & 0,727 & 0,220 & Valid \\
\hline 6 & 0,542 & 0,220 & Valid \\
\hline 7 & 0,626 & 0,220 & Valid \\
\hline 8 & 0,698 & 0,220 & Valid \\
\hline 9 & 0,653 & 0,220 & Valid \\
\hline 10 & 0,609 & 0,220 & Valid \\
\hline
\end{tabular}

Sumber: data yang diolah 2019

Tabel 4

Uji Validitas Variabel $\mathrm{X}_{3}$

\begin{tabular}{|c|c|c|c|}
\hline Pertanyaan & $\mathbf{r}_{\text {hitung }}$ & $\mathbf{r}_{\text {tabel }}$ & Keterangan \\
\hline 1 & 0,434 & 0,220 & Valid \\
\hline 2 & 0,515 & 0,220 & Valid \\
\hline 3 & 0,453 & 0,220 & Valid \\
\hline 4 & 0,625 & 0,220 & Valid \\
\hline 5 & 0,625 & 0,220 & Valid \\
\hline
\end{tabular}

\begin{tabular}{|c|c|c|c|}
\hline Pertanyaan & $\mathbf{r}_{\text {hitung }}$ & $\mathbf{r}_{\text {tabel }}$ & Keterangan \\
\hline 6 & 0,681 & 0,220 & Valid \\
\hline 7 & 0,663 & 0,220 & Valid \\
\hline 8 & 0,638 & 0,220 & Valid \\
\hline 9 & 0,701 & 0,220 & Valid \\
\hline 10 & 0,657 & 0,220 & Valid \\
\hline
\end{tabular}

Sumber: data yang diolah 2019

Tabel 5

Uji Validitas Variabel Y

\begin{tabular}{|c|c|c|c|}
\hline Pertanyaan & $\mathbf{r}_{\text {hitung }}$ & $\mathbf{r}_{\text {tabel }}$ & Keterangan \\
\hline 1 & 0,520 & 0,220 & Valid \\
\hline 2 & 0,509 & 0,220 & Valid \\
\hline 3 & 0,304 & 0,220 & Valid \\
\hline 4 & 0,726 & 0,220 & Valid \\
\hline 5 & 0,761 & 0,220 & Valid \\
\hline 6 & 0,567 & 0,220 & Valid \\
\hline 7 & 0,653 & 0,220 & Valid \\
\hline 8 & 0,613 & 0,220 & Valid \\
\hline 9 & 0,649 & 0,220 & Valid \\
\hline 10 & 0,663 & 0,220 & Valid \\
\hline
\end{tabular}

Sumber: data yang diolah 2019

Dari table di atas dapat dilihat bahwa nilai $r_{\text {hitung }}$ masing-masing variable lebih besar dari $\mathrm{R}_{\text {tabel. }}$. Dapat disimpulkan bahwa semua item pertanyaan masing-masing variable dinyatakan valid (dipakai).

\subsection{Uji Reliabilitas}

Dalam penelitian ini uji reliabilitas dicari menggunakan rumus Alpha.Rumus Alpha digunakan untuk mencari reliabilitas instrumen yang skornya bukan 1 dan 0 . Instrumen dapat dikatakan reliabel jika nilai koefisien alpha tersebut melebihi 0,6 (Ali Muhson: 2009).

Tabel 6

Hasil Uji Reabilitas Instrumen

\begin{tabular}{|l|c|c|c|}
\hline \multicolumn{1}{|c|}{ Variabel } & $\begin{array}{c}\text { Nilai Alfa } \\
\text { Chonbach }\end{array}$ & $\begin{array}{c}\text { Cronbach Alfa } \\
\text { Standard }\end{array}$ & Keterangan \\
\hline Komitmen Organisasi & 0,708 & 0,600 & Reliabel \\
\hline Profesionalisme & 0,750 & 0,600 & Reliabel \\
\hline Kompetensi Guru & 0,746 & 0,600 & Reliabel \\
\hline Kinerja Guru & 0,746 & 0,600 & Reliabel \\
\hline
\end{tabular}

\subsection{Uji Asumsi Klasik}

\subsubsection{Uji Normalitas}

Adapun hasil pengujian Normalitas dalam penelitian ini menggunakan pendekatan grafik dengan P-P Plot dan juga uji yang dapat pada gambar berikut: 


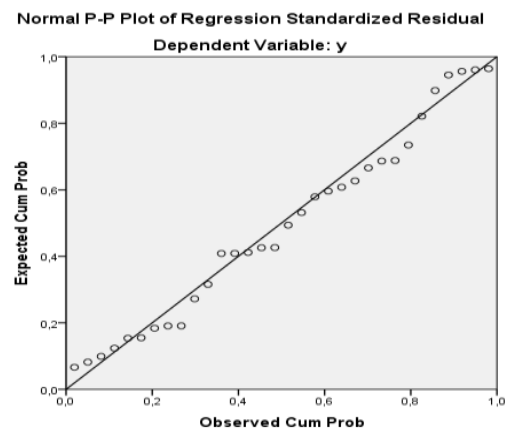

Gambar 1. Hasil Uji Normalitas dengan P-P Plot
Berdasarkan hasil uji normalitas dengan P-P Plot pada gambar diatas dapat dilihat bahwa plot menyebar mengikuti atau searah dengan garis diagonal, sehingga dapat disimpulkan bahwa model regresiyang digunakan dalam penelitian ini normal dan dapat digunakan.

\subsubsection{Uji Multikolinearitas}

Adapun hasil pengujian Multikolinearitas dalam penelitian ini dapat dilihat pada table berikut :

\section{Tabel 7}

Hasil Uji Multikolinearitas

Coefficients $^{\mathrm{a}}$

\begin{tabular}{|c|c|c|c|c|c|}
\hline \multirow{2}{*}{ Variable } & \multicolumn{2}{|c|}{$\begin{array}{c}\text { Unstandardized } \\
\text { Coefficients }\end{array}$} & $\begin{array}{c}\text { Standardized } \\
\text { Coefficients }\end{array}$ & \multicolumn{2}{c|}{ Collinearity Statistics } \\
\cline { 2 - 6 } & B & Std. Error & Beta & Tolerance & VIF \\
\hline (Constant) & 19,768 & 10,388 & & & \\
\hline X1 &, 110 &, 158 &, 117 &, 943 & 1,060 \\
\hline X2 &, 118 &, 107 &, 184 &, 961 & 1,040 \\
\hline X3 &, 349 &, 132 &, 451 &, 909 & 1,101 \\
\hline
\end{tabular}

Sumber data diolah dengan SPSS 24, 2019

Uji Multikolinearitas digunakan untuk melihat apakah pada model regresi ditemukan adanya korelasi antar variable bebas. Jika terjadi Korelasi, maka dinamakan terdapatnya problem multikolinearitas. Cara mengetahuinya adalah dengan melihat nilai Variance Inflation Factor (VIF). Apabila nilai Tolerance $<0,10$ dan nilai VIF > 10,00 maka terjadi Multikolinearitas. Pada output SPSS versi 24, angka tolerance > 10,00 dan nilai VIF $<10,00$ maka hal ini tidak terjadi multikolinearitas.

\subsubsection{Uji Heteroskedastisitas}

Adapun hasil pengujian heteroskedastisitas dalam penelitian ini dapat dilihat pada gambar berikut :

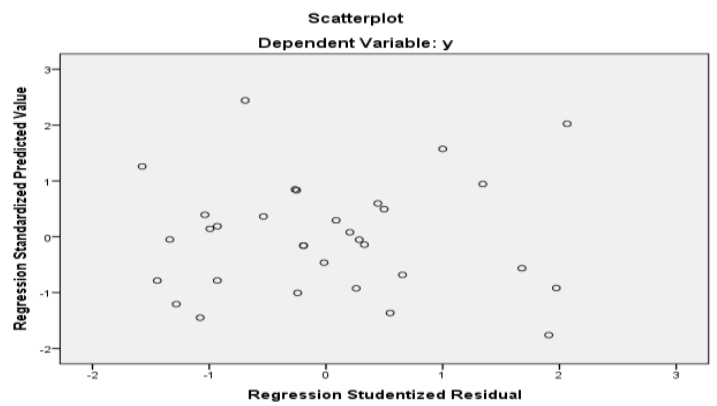

Gambar 2 Hasil Uji Heteroskedastisitas dengan Scatter Plot
Berdasarkan hasil pengujian heteroskedastisitas pada gambar diatas dapat dilihat bahwa plot menyebar secara acak di antara sumbu $\mathrm{X}$ dan $\mathrm{Y}$ sehingga dapat disimpulkan bahwa tidak terdapat gejala heteroskedastisitas pada model regresi yang digunakan dalam penelitian ini dan model regresi telah memenuhi syarat uji heteroskedastisitas.

\subsection{Analisis Regresi Linear Berganda}

Adapun hasil regresi linear berganda dalam penelitian ini dapat dilihat pada tabel berikut ini:

Tabel 8

Hasil Regresi Linear Berganda Coefficients $^{\mathrm{a}}$ 


\begin{tabular}{|c|c|c|c|c|c|}
\hline \multirow{2}{*}{ Variable } & \multicolumn{2}{|c|}{$\begin{array}{c}\text { Unstandardized } \\
\text { Coefficients }\end{array}$} & $\begin{array}{c}\text { Standardized } \\
\text { Coefficients }\end{array}$ & \multirow{2}{*}{$\mathrm{t}$} & \multirow{2}{*}{ Sig. } \\
\cline { 2 - 4 } & $\mathrm{B}$ & Std. Error & Beta & & \\
\hline (Constant) & 19,768 & 10,388 & & 2,903 &, 017 \\
\hline $\mathrm{X}^{1}$ &, 110 &, 158 &, 117 & 3,699 &, 049 \\
\hline $\mathrm{X}^{2}$ &, 118 &, 107 &, 184 & 4,107 &, 028 \\
\hline $\mathrm{X}^{3}$ &, 349 &, 132 &, 451 & 4,644 &, 013 \\
\hline
\end{tabular}

Sumber data diolah dengan SPSS 24, 2019

Berdasarkan hasil regresi linear berganda pada tabel diatas maka dapat dibuat persamaan sebagai berikut :

$$
\begin{aligned}
& \text { Kinerja }=19,768+, 110 X_{1}+, 118 X_{2}+ \\
& , 349 X_{3}
\end{aligned}
$$

Berdasarkan hasil persamaan tersebut maka dapat diuraikan penjelasan sebagai berikut :

1. Nilai Konstanta sebesar 19,768 memberikan arti bahwa jika secara keseluruhan nilai variable $\quad\left(\right.$ SinismeX ${ }^{1}, \quad$ Kecerdasan EmosionalX ${ }^{2}$, Stres KerjaX ${ }^{3}$ ) naik masing sebesar $1_{\mathrm{a}}$ maka nilai Kinerja (Y) akan naik menjadi 19,768 .

2. Nilai koefisien Komitmen organisasi sebesar 0,110 memberikan arti bahwa jika nilai Komitmen Organisasi naik sebesar $1_{\mathrm{a}}$ maka nilai kinerja juga akan naik sebesar 0,110 . Nilai koefisienyang positif memberikan arti bahwa Komitmen Organisasi memberikan pengaruh positif terhadap Kinerja.

3. Nilai koefisien Profesionalisme sebesar 0,118 memberikan arti bahwa jika nilai Profesionalisme naik sebesar $1_{\mathrm{a}}$ maka nilai kinerja juga akan naik sebesar 0,118 . Nilai koefisien yang positif memberikan arti bahwa Profesionalisme memberikan pengaruh positif terhadap Kinerja.

4. Nilai koefisien Kompetensi Guru sebesar 0,349 memberikan arti bahwa jika nilai Kompetensi Guru naik sebesar $1_{\mathrm{a}}$ maka nilai kinerja juga akan naik sebesar 0,349. Nilai koefisien yang positif memberikan arti bahwa Kompetensi Guru memberikan pengaruh positif terhadap Kinerja.

\subsection{Uji Signifikan Simultan (Uji F)}

Uji serempak dilakukan untuk melihat tingkat signifikansi variabel bebas secara bersama sama berpengaruh terhadap variabel terikat. Hasil uji secara serempak dapat dilihat pada tabel dibawah ini :

Tabel 9

Uji Simultan (Uji F)

ANOVA $^{\mathrm{a}}$

\begin{tabular}{|l|r|r|r|r|r|}
\hline Model & Sum of Squares & \multicolumn{1}{|c|}{ Df } & Mean Square & \multicolumn{1}{c|}{ F } & \multicolumn{1}{c|}{ Sig. } \\
\hline Regression & 36,163 & 3 & 12,054 & 13,252 & $.004^{\mathrm{b}}$ \\
1 Residual & 103,805 & 28 & 3,707 & & \\
Total & 139,969 & 31 & & & \\
\hline
\end{tabular}

a. Dependent Variable: $Y$

b. Predictors: (Constant), X3, X2, X1

Tabel 9 diatas menunjukkan bahwa nilai signifikansi adalah sebesar 0.004. Nilai signifikansi tersebut lebih kecil dibandingkan dengan nilai Alpha sebesar 0.05. Sehingga dapat disimpulkan bahwa secara bersama sama (variable Komitmen Organisasi, Profesionalisme dan Kompetensi) berpengaruh signifikan terhadap Kinerja Guru di SMPN 1 IDI Kabupaten Aceh Timur.

\subsection{Uji Signifikan Parsial (t)}

Uji parsial (Uji t) dilakukan untuk menjawab pertanyaan yang telah diajukan baik pada identifikasi, rumusan masalah maupun hipotesis penelitian secara parsial atau individu.

Tabel 10

\begin{tabular}{|c|c|c|c|c|c|}
\hline \multirow{3}{*}{ Variable } & \multicolumn{2}{|c|}{$\begin{array}{c}\text { Unstandardized } \\
\text { Coefficients }\end{array}$} & $\begin{array}{c}\text { Standardized } \\
\text { Coefficients }\end{array}$ & \multirow{2}{*}{$\mathrm{t}$} & \multirow{2}{*}{ Sig. } \\
\cline { 2 - 4 } & $\mathrm{B}$ & Std. Error & Beta & & \\
\hline (Constant) & 19,768 & 10,388 & & 2,903 &, 017 \\
\hline $\mathrm{X}^{1}$ &, 110 &, 158 &, 117 & 3,699 &, 049 \\
\hline $\mathrm{X}^{2}$ &, 118 &, 107 &, 184 & 4,107 &, 028 \\
\hline
\end{tabular}




\begin{tabular}{|c|c|c|c|c|c|}
\hline $\mathrm{X}^{3}$ &, 349 &, 132 &, 451 & 4,644 &, 013 \\
\hline
\end{tabular}

Tabel 10 diketahui bahwa nilai signifikansi dari Komitmen Organisasi $\left(\mathrm{X}_{1}\right)$ adalah 0.049 nilai ini lebih kecil dari nilai alphanya yang sebesar 0.05 . Dengan demikian dapat dinyatakan bahwa Pengaruh Komitmen Organisasi berpengaruh positif dan signifikan terhadap Kinerja Guru, Selanjutnya diketahui bahwa nilai signifikansi dari Profesionalisme $\left(\mathrm{X}_{2}\right)$ adalah 0.028 nilai ini lebih kecil dari nilai alphanya yang sebesar 0.05 . Dengan demikian dapat dinyatakan bahwa Profesionalisme memiliki pengaruh positif dan signifikan terhadap Kinerja Guru. Selanjutnya di ketahui bahwa nilai signifikansi Kompetensi Guru $\left(\mathrm{X}_{3}\right)$ adalah 0,013 nilai ini lebih kecil dari 0,05 dengan demikian Kompetensi Gurumemiliki pengaruh positif dan signifikan

Tabel 11

Koefisien Determinasi Model Summary ${ }^{\mathrm{b}}$

\begin{tabular}{|l|r|r|r|r|r|r|}
\hline Model & $\mathrm{R}$ & $\mathrm{R}$ Square & $\begin{array}{c}\text { Adjusted R } \\
\text { Square }\end{array}$ & $\begin{array}{c}\text { Std. Error of the } \\
\text { Estimate }\end{array}$ & \multicolumn{2}{|c|}{ Change Statistics } \\
\cline { 6 - 7 } & & & & $\begin{array}{c}\text { R Square } \\
\text { Change }\end{array}$ & F Change \\
\hline 1 & $.508^{\mathrm{a}}$ & .258 &, 179 & 1,92544 & $.508^{\mathrm{a}}$ & .258 \\
\hline
\end{tabular}
$\begin{aligned} & \text { a. Predictors: (Constant), } X 3, X 2, X 1 \\
& \text { b. Dependent Variable: } Y\end{aligned}$

Berdasarkan pada tabel 2.11 diketahui bahwa nilai R-Square adalah sebesar 0,258. Artinya bahwa Komitmen Organisasi, Profesionalisme dan Kompetensi Guru mampu menjelaskan Kinerja Guru sebesar 25,8\% sisanya 74,2\% dijelaskan oleh variabel lain yang tidak dimasukkan ke dalam model penelitian ini.

\section{Kesimpulan}

Berdasarkan pada analisis dan evaluasi data di atas, maka kesimpulan dari penelitian ini adalah:

1. Variabel Komitmen Organisasi terhadap Kinerja guru di SMPN I IDI Kabupaten Aceh Timur dengan nilai $t_{\text {hitung }}>t_{\text {tabel }}(3,699$ $>2.045$ )

2. Variabel profesionalisme terhadap Kinerja guru di SMPN I IDI Kabupaten Aceh Timur dengan nilai $t_{\text {hitung }}>t_{\text {tabel }}(4,107>2.045)$

3. Variabel kompetensi Guru terhadap Kinerja guru di SMPN I IDI Kabupaten Aceh Timur dengan nilai $t_{\text {hitung }}>t_{\text {tabel }}(4,644>2.045)$

4. Variabel Komitmen Organisasi, Profesionalisme dan Kompetensi Guru terhadap Kinerja guru di SMPN I IDI terhadap Kinerja Guru di SMPN 1 IDI Kabupaten Aceh Timur.Hal ini dapat kita ketahui Pengaruh Komitmen Organisasi, Profesionalisme dan Kompetensi Guru berpengaruh positif dan signifikan terhadap kinerja Guru di SMPN 1 IDI Kabupaten Aceh Timur.

\subsection{Uji Determinasi (R Square)}

Untuk dapat mengetahui besarnya Pengaruh Komitmen Organisasi, Profesionalisme dan Kompetensi Gurudalam menjelaskan Kinerja Guru dapat dilihat pada koefisien determinasinya yang berada pada tabel 2.11 berikut
Kabupaten Aceh Timur dengan nilai $\mathrm{F}_{\text {hitung }}>$ $\mathrm{F}_{\text {tabel }}(13,252>2.93)$

\section{DAFTAR PUSTAKA}

Adlina Setiani (2014) "Pengaruh kualitas kehidupan kerja terhadap kinerja dengan komitmen organisasi intervening variable"Skripsi, Universitas Cakrawala, Madiun.

Amirullah, dan Hanafi, Rindyah. 2012. Pengantar Manajemen. Yogyakarta : Graha Ilmu.

Anoraga, Panji. 2008. Psiklogi Mengajar. Jakarta : PT. Rineka Cipta.

Arikunto, Suharsimi. 2012. Prosedur Penelitian Suatu Pendekatan Praktek. Jakarta : Pt. Rhineka. Cipta.

Bafadal, Ibrahim. 2013. Peningkatan Profesionalisme Guru Sekolah Dasar. Jakarta. PT. Rineka Cipta

Benardi, Ressel (2011), Manajemen Sumber Daya Manusia, PT. Preshelindo, Jakarta.

Danim, Sudarman. 2013. Agenda Pembaharuan Sistem Pendidikan. Jakarta : Pustaka Belajar. 
Dessler, G. 2. (2008). Human Resource Management 11th ed. New Jersey: Pearson Prentice Hall.

Fattah, Nanang. 2013. Landasan Kependidikan. Bandung : PT. Remaja Rodaskarya.

Gardener, Howard. 2004. Teori Inteligensi Ganda dan Aplikasinya Di Sekolah. Yogyakarta : Kanisius.

Garis-garis Besar Program Pendidikan dan Pelatihan Produktif. 2009. Jakarta. Departemen Pendidikan dan Kebudayaan.

Hakim. (2008). Analisis Pengaruh Motivasi, Komitmen Organisasi Dan Iklim Organiasasi terhadap pegawai. JRBI Vol 2 No 2, 165-180

Hamalik, Umar. 2014. Kurikulum dan Pembelajaran. Bandung : Bumi Aksara.

Hasibuan, Melayu SP. 2013. Organisasi dan Motivasi. Jakarta : PT. Bumi Aksara

Mathis, Robert L dan Jackson, Jhon H. 2012. Manajemen SDM. Jakarta : Salemba Empat.

Nazir, Moh. 2009. Metode Penelitian. Jakarta : Ghalia Putra.

Nitisemito S Alex (2011), Manajemen Personalia, Cetakan Keempat, Ghalia, Jakarta.

Purwanto, Ngalim. 2013. Psikologi Pendidikan. Bandung : PT. Remaja Rosdakarya.

Regina Aditya Reza(2010)"Pengaruh gaya kepemimpinan, motivasi dan disiplin terhadap kinerja karyawan PT. Sinar Santosa Perkasa

Banjarnegara"Skripsi,Universitas Cakrawala, Madiun.

Riski Yunida (2016)“Hubungan Sinisme Organisasi dengan Komitmen Organisasi pada Karyawan PT. Hasnur Citra Terpadu di Banjarmasin"Skripsi, Universitas Achmad Yani, Banjarmasin.

Rivai, Veithzal dan Sagala, Ella Jauvani. (2009). Manajemen Sumber Daya Manusia Untuk Perusahaan : Dari Teori ke Praktek. Jakarta : PT. Rajagrafindo Persada

Robbins, Stephen P. 2011. Perilaku Organisasi Jilid I. Yogyakarta : Aditya Media.

Sadarmayanti. 2011. SDM dan Produktivitas Mengajar, Bandung : Mandar Maju.

Sevilla, Consuelo G. et. al (2008). Research Methods. Rex Printing Company. Quezon City

Singgih, Santoso. 2010. Manajemen Modern (Konsep dan Aplikasi. Bandung : Sinar Biru.
Sinungan (2011), Filsafat Administrasi, Gunung Agung Jakarta

Siswanto, Bedjo. 2009. Manajemen Modern (Konsep dan Aplikasi. Bandung : Sinar Biru.

Soekartawi. 2013. Meningkatkan Efektivitas Mengajar. Jakarta : PT Dunia Pustaka Jaya

Soeparwoto, dkk. 2013. Psikologi Perkembangan. Semarang. UPT MKK UNNES.

Standar Kompetensi Guru Sekolah Menegah Atas. 2009. Jakarta. Depdiknas.

Sudjana, Nana. 2014. Dasar-dasar Proses Belajar Mengajar. Bandung : Sinar Baru Algensindo.

Sudjana. 2012. Metode Statistik. Bandung : Transito.

Sugiyono (2009), Metodologi Penelitian, Alpha Beta Bandung

Sunarto dan Hartono Agung. 2008. Perkembangan peserta Didik. Jakarta : PT Rineka Cipta.

Suparno, Paul. 2013. Guru Demokrasi Di Era Reformasi Pendidikan. Jakarta : PT Gramedia.

Tilaar, H A R. 2012. Pendidikan Untuk Masyarakat Indonesia Baru. Jakarta : Grasindo.

Triton PB (2015), Paradigma Baru Manajemen Sumber Daya Manusia, Tugu Yogyakarta.

Winardi. 2012. Motivasi dan Permotivasian Dalam Manajemen. Jakarta : PT Raja Grafindo Persada.

Yeltsin Aprrioke Thomas(2010) "Pengaruh fasilitas kerja terhadap kinerja PNS di Kantor Dinas Pendidikan Minahasa Tenggara"Skripsi, Universitas Negeri Manado.

Yudiningsih (2012) "Pengaruh Disiplin Kerja dan Kecerdasan Emosinal Terhadap Kinerja Pegawai Pada Distanak Kabupaten Buleleng”. Skripsi, Universitas Panji Sakti, Singaraja. 